\title{
Threatened fishes of the world: the end of a series
}

\author{
David L. G. Noakes • Lynn D. Bouvier
}

Published online: 24 August 2013

(C) Springer Science+Business Media Dordrecht 2002

Our series of manuscripts on Threatened Fishes of the World came to an end after a prolonged and increasingly depressing and frustrating history. Prolonged because the series extended from 1995 to 2013, much longer than was anticipated. Increasingly depressing because it became clear to even the most skeptical reader that the status of a great many fishes is a matter of real concern. Frustrating because the accounts mostly presented the same picture for almost every species.

The species accounts range from the largest fish species, the whale shark (Rhincodon typus) to one of the smallest (Tanichthys albonubes), in freshwater, marine and brackish water systems (Table 1). The list includes some species that almost certainly are extinct, such as the Yangtze paddlefish (Xiphurus gladius), and some that are relatively abundant and widespread, such as the North American lake sturgeon (Acipenser fulvescens). Some species have global distributions, other are restricted to a single desert spring (Cyprinodon diabolis).

Several cautions are obvious for this species list. Since contributions were unsolicited, and judged on their

\section{L. G. Noakes $(\bowtie)$}

Fisheries and Wildlife Department and Oregon Hatchery Research Center, Oregon State University, Corvallis, OR 97331-3803, USA

e-mail: David.Noakes@oregonstate.edu

\section{D. Bouvier}

Great Lakes Laboratory for Fisheries and Aquatic Sciences, Fisheries and Oceans Canada, 867 Lakeshore Road,

Burlington, Ontario L7R 4A6, Canada individual merits, it is not possible to analyze or interpret these reports as any objective measure of the number or distribution of threatened fish species. That was never the intention of this series. Other publications (Helfman 2007) are definitive efforts that were designed to address those important questions (Albins et al. 2013). Similarly, it is not possible to draw any conclusions from our series on Threatened Fishes as to the geographic, phylogenetic or systematic distribution of species. In fact, some papers must be regarded as doubtful reports of threatened species, since they probably represent only local color variants of broadly distributed species that cannot be considered as threatened (e.g., the aurora form of Salvelinus fontinalis, Salmo trutta caspias).

We still receive a few manuscript submission each year, although the journal website clearly states that we are no longer accepting manuscripts for the series. It proved to be increasingly difficult to judge the claimed threatened status for taxonomic units reported from areas with very limited information on species distributions and abundance. Helfman (2013) has done an admirable job to demonstrate the profound differences and difficulties that exist among different countries and jurisdictions where there is reasonable confidence for species identification and knowledge of population status. It is a simple exercise for any undergraduate ichthyology class in almost any place on earth to demonstrate that we have very limited information on the biology, ecology and population status of most local fish species (Scott and Crossman 1973).

I organized an invited session on Threatened Fishes for the annual meeting of the AAAS in Chicago in February 2011. Several papers from that session are 
Table 1 Summary of 359 manuscripts published in the Threatened Fishes of the World series. Distributional information taken from Froese and Pauly (2013)

\begin{tabular}{|c|c|c|}
\hline Species & Distribution & Environment \\
\hline Acanthobrama hadiyahensis & Asia: Saudi Arabia & Freshwater \\
\hline Acanthobrama mirabilis & $\begin{array}{l}\text { Asia: Only known by the original description from Büyük } \\
\text { Menderes and two more specimens from the Bafa Gölü } \\
\text { in Southwestern Anatolia }\end{array}$ & Freshwater \\
\hline Acheilognathus elongatus & Asia: Dian Chi Lake, Yunnan, China & Freshwater \\
\hline Achondrostoma occidentale & $\begin{array}{l}\text { Europe: Alcabrichel, Sizandro and Safarujo drainages in } \\
\text { Estremadura, Portugal }\end{array}$ & Freshwater \\
\hline Acipenser brevirostrum & $\begin{array}{l}\text { North America: St. John River in Canada to St. Johns River } \\
\text { in Florida, USA }\end{array}$ & Anadromous \\
\hline Acipenser dabryanus & Asia: China in Yangtze River system and Korea & Freshwater \\
\hline Acipenser fulvescens & $\begin{array}{l}\text { North America: St. Lawrence-Great Lakes, Hudson Bay, and } \\
\text { Mississippi River basins }\end{array}$ & Anadromous \\
\hline Acipenser gueldenstaedtii & $\begin{array}{l}\text { Eurasia: Black Sea, Sea of Azov and Caspian Sea, entering } \\
\text { all main rivers that empty into them (Don, Kuban, Danube, } \\
\text { Dnieper (rare), Dniester). Introduced throughout Europe }\end{array}$ & Anadromous \\
\hline Acipenser naccarii & $\begin{array}{l}\text { Europe: Adriatic Sea and its tributaries between Po (Italy) and } \\
\text { Buna (Albania) drainages. Recorded from Corfu; present in } \\
\text { lowermost part of Adriatic rivers from Soca to Drin. Records } \\
\text { from Tyrrhenian slope of Italy, Spain and France are erroneous }\end{array}$ & Anadromous \\
\hline Acipenser nudiventris & $\begin{array}{l}\text { Europe: Black, Azov, Caspian and Aral Sea, ascending some } \\
\text { rivers (Danube up to Bratislava, Volga up to Kazan, Ural up to } \\
\text { Chkalov), unknown or very rare in others. On the verge of } \\
\text { extinction in its natural range. Extirpated in Aral basin; nearly } \\
\text { extirpated in Black Sea basin; only occasional records from } \\
\text { Danube and lower Volga; only a very small population remaining } \\
\text { in Rivers Ural (Russia, Kazakhstan) and Rioni (Georgia); no } \\
\text { natural spawning population in Iran; established in Lake Balkhash } \\
\text { where it forms a large population }\end{array}$ & Anadromous \\
\hline Acipenser oxyrinchus & $\begin{array}{l}\text { Western Atlantic: Hamilton River, Labrador, Newfoundland, Canada } \\
\text { to northeastern Florida, USA. Occurs occasionally in Bermuda } \\
\text { and French Guiana. Northern Gulf of Mexico. In Europe: Baltic } \\
\text { Sea. Landlocked populations in Lakes Ladoga and Onega (Russia), } \\
\text { both now extirpated. Occasionally recorded from Great Britain and } \\
\text { North Sea in Elbe drainage. Recent research revealed that this } \\
\text { species existed in the Baltic Sea, but is now extirpated. Near } \\
\text { threatened globally, but extirpated in Europe }\end{array}$ & Anadromous \\
\hline Acipenser persicus & $\begin{array}{l}\text { Eurasia: Caspian basin, most abundant in the southern part. Also } \\
\text { distributed along the eastern Black Sea }\end{array}$ & Potamodromous \\
\hline Acipenser ruthenus & $\begin{array}{l}\text { Eurasia: rivers draining to Black, Azov and Caspian Seas; Siberia } \\
\text { from Ob eastward to Yenisei drainages. Introduced throughout } \\
\text { Europe, without formation of self-sustaining populations. Appendix } \\
\text { III of the Bern Convention (protected fauna). International trade } \\
\text { restricted }\end{array}$ & Freshwater, brackish \\
\hline Acipenser schrenckii & $\begin{array}{l}\text { Asia: Endemic to the Amur River system. Two morphs, brown and } \\
\text { gray, represent the species in the Amur River basin }\end{array}$ & $\begin{array}{l}\text { Marine; freshwater; } \\
\text { brackish }\end{array}$ \\
\hline Acipenser sinensis & Northwest Pacific: China and Japan (Sagami Sea) & $\begin{array}{l}\text { Marine; freshwater; } \\
\text { brackish }\end{array}$ \\
\hline Acipenser stellatus & $\begin{array}{l}\text { Eurasia: Caspian, Black, Azov and Aegean Seas, ascending } \\
\text { rivers to spawn }\end{array}$ & $\begin{array}{l}\text { Marine; freshwater; } \\
\text { brackish }\end{array}$ \\
\hline Acipenser sturio & $\begin{array}{l}\text { Eastern Atlantic: the only remaining spawning population occurs } \\
\text { in the Garonne drainage in France. Used to range from Norway }\end{array}$ & $\begin{array}{l}\text { Marine; freshwater; } \\
\text { brackish }\end{array}$ \\
\hline
\end{tabular}


Table 1 (continued)

\begin{tabular}{lll}
\hline Species & Distribution & Environment \\
\hline
\end{tabular}

Allotoca goslinei

Alosa alabamae

Amblyceps mangois

Amblyopsis rosae

Amblyopsis spelaea

Ameca splendens

Anabarilius alburnops

Anabarilius grahami

Anabarilius polylepis

Anaecypris hispanica

Aphanius baeticus

Aphanius iberus

Aphyocypris lini

Aspiorhynchus laticeps

Astroblepus ubidiai

Aulopyge huegelii

Austroglanis barnardi

Austrolebias nigrofasciatus

Austrolebias univentripinnis

Bahaba taipingensis

Barbus andrewi

Barbus calidus

Barbus caninus

Barbus capensis

Barbus comiza

Barbus ethiopicus

Barbus goktschaicus

Barbus haasi

Barbus serra

Barbus treurensis to the Bay of Biscay, including the North Sea, European coasts of Atlantic, northern Mediterranean eastward to Rhodos, western and southern Black Sea; occasionally recorded from the White Sea, Iceland, Morocco and Algeria. Anadromous, in most large rivers, but not recorded from Danube upriver of delta

Central America: Ameca River basin, Jalisco, Mexico

Western Central Atlantic: Gulf of Mexico

Asia: Pakistan to Thailand

North America: Springfield Plateau in southwestern Missouri, northeastern Oklahoma and northwestern Arkansas (Arkansas and upper White River drainages), USA

North America: Indiana and Kentucky, USA

North America: Jalisco, Mexico

Asia: restricted to southwest China

Asia: restricted to southwest China

Asia: Yunnan, China

Europe: Guadiana drainage in Spain and Portugal

Europe: Spain along Atlantic coast between Huelva and Gulf of Cadiz, known from 9 localities

Europe: Spain along Mediterranean coast from 30 known localities (now extirpated in 14 of them). Historical records from near Perpignan, France now extirpated

Asia: southern China

Asia: Boston Lake and Yarkant River in Xinjiang Autonomous Region, China

South America: Mira River basin and Pacific coastal drainages of Ecuador

Europe: Croatia (Cetina, Krka and Zrmanja drainages) and Bosnia-Herzegovina (Karstic streams in Glamocko, Livanjsko and Duvanjsko poljes, Lakes Busko and Blidinje)

Africa: Clanwilliam Olifants River system, South Africa

South America: inner drainages between laguna dos Patos and lagoa Mirim, southern Brazil

South America: Mirim Lagoon basin in Brazil

Northwest Pacific: south China only. From the Yangtze River southwards to Hongkong

Africa: Berg and Breë systems, south-western Cape Province, South Africa

Africa: tributaries of the Clanwilliam Olifants, western Cape, South Africa

Europe: Adriatic basin, between Marecchia and Brenta drainages (Italy, Switzerland)

Africa: Clanwilliam Olifants River system, South Africa

Europe: Portugal and Spain in Tagus and Guadiana drainages. Extirpated in Guadalquivir drainage, Spain

Africa: endemic to Ethiopia

Asia: Lake Sevan and its tributaries

Europe: Mediterranean slope of Spain from Llobregat to Riudecanyes drainages

Africa: Olifants River system, western Cape Province, South Africa
Freshwater

Marine; freshwater; brackish

Freshwater

Potamodromous

Freshwater

Freshwater

Freshwater

Freshwater

Freshwater

Freshwater

Freshwater

Freshwater, brackish

Freshwater

Freshwater

Freshwater

Freshwater

Freshwater

Freshwater

Freshwater

Marine, brackish

Freshwater

Freshwater

Freshwater

Freshwater

Freshwater

Freshwater

Freshwater

Freshwater

Freshwater

Freshwater 
Table 1 (continued)

\begin{tabular}{lcc}
\hline Species & Distribution & Environment \\
\hline
\end{tabular}

Barbus trevelyani

Batrochoglanis mathisoni

Bolbometopon muricatum

Boleophthalmus pectinirostris

Brachionichthys hirsutus

Brachymystax lenok

Brachymystax lenok tsinlingensis

Brycon nattereri

Caecobarbus geertsii

Capoeta antalyensis

Capoeta bergamae

Capoeta pestai

Carcharias taurus

Carcharodon carcharias

Catostomus warnerensis

Cetorhinus maximus

Chalcalburnus tarichi

Chasmistes liorus

Cheilinus undulatus

Chiloglanis bifurcus

Chiloglanis emarginatus
Africa: upper reaches of Blyde River, Limpopo system, eastern Transvaal, South Africa; previously known from the Treur and Sabie rivers

Africa: Keiskamma and Buffalo systems in the Ciskei and eastern Cape Province, South Africa

Indo-Pacific: Red Sea and East Africa to Samoa and the Line Islands, north to the Yaeyama and Wake islands, south to the Great Barrier Reef and New Caledonia

Northwest Pacific: China, Korean Peninsula, Japan and Taiwan

Southwest Pacific: Endemic to Tasmania, Australia

Asia: Siberia, Korea and North China. A subspecies, Brachymystax lenok tsinlingensis is endemic to parts of the Taibaishan Mountain in the Qinling Mountains, particularly in the Heihe River at the eastern foot, the Shitouhe River at the northern foot and the Xushui and Taibaihe rivers at the southern foot of the mountain

Asia: Siberia, Korea and North China. A subspecies, Brachymystax lenok tsinlingensis is endemic to parts of the Taibaishan Mountain in the Qinling Mountains, particularly in the Heihe River at the eastern foot, the Shitouhe River at the northern foot and the Xushui and Taibaihe rivers at the southern foot of the mountain

South America: Upper Paraná and São Francisco River basins in Brazil

Africa: known only from some caves near Mbanza-Ngungu (lower Congo River), Democratic Republic of Congo

Asia: Turkey

Asia: Turkey

Asia: endemic to Turkey

Circumtropical: Except perhaps the eastern Pacific. Indo-West Pacific: Red Sea and off South Africa to Japan, Korea and Australia. Present in Arafura Sea. Western Atlantic: Gulf of Maine to Argentina. Old record from Bermuda, south Brazil. Eastern Atlantic: Mediterranean to Cameroon. Northwest Atlantic: Canada

Cosmopolitan, mostly amphitemperate. Western Atlantic: Newfoundland, Canada to Argentina; also north Gulf of Mexico, Bahamas, Cuba and Lesser Antilles

North America: restricted to Warner Lake basin in southern Oregon, USA

Cosmopolitan. Western Atlantic: Newfoundland, Canada to Florida, USA; southern Brazil to Argentina. Eastern Atlantic: Iceland, Norway and western Barents Sea to the North Sea, Mediterranean and Senegal; also western Cape Province, South Africa. Western Pacific: Japan to New Zealand. Eastern Pacific: Gulf of Alaska to Chile; possibly the Galapagos Islands. Highly migratory species, Annex I of the 1982 Convention on the Law of the Sea

Asia: endemic to Lake Van Gölü, Turkey

North America: endemic to Utah Lake and lower Provo River in Utah, USA

Indo-Pacific: Red Sea to South Africa and to the Tuamoto Islands, north to the Ryukyu Islands, south to New Caledonia

Africa: Endemic to the Crocodile-Incomati system
Freshwater

Marine

Marine; freshwater; brackish

Marine

Freshwater

Freshwater

Freshwater

Freshwater

Freshwater

Freshwater

Freshwater

Marine

Marine

Freshwater

Marine

Freshwater

Freshwater

Marine

Freshwater

Freshwater 
Table 1 (continued)

\begin{tabular}{|c|c|c|}
\hline Species & Distribution & Environment \\
\hline & $\begin{array}{l}\text { Africa: two areas, tributaries of the Pongolo and Komato-Incomati } \\
\text { rivers in South Africa and Swaziland, and the Pungwe and middle } \\
\text { and lower Zambezi in Zimbabwe }\end{array}$ & \\
\hline Chirostoma aculeatum & North America: endemic to the Lerma River basin & Freshwater \\
\hline Chirostoma riojai & North America: endemic to the Lerma River basin & Freshwater \\
\hline Chlamydogobius micropteru & Oceania: Queensland, Australia & Freshwater \\
\hline Chondrostoma arrigonis & Europe: Júcar River basin, eastern Spain & Freshwater \\
\hline Chondrostoma beysehirense & Asia: Beysehir Lake, Turkey & Freshwater \\
\hline Chondrostoma knerii & Europe: Neretva drainage in Croatia and Bosnia Herzegovina & Freshwater \\
\hline Chondrostoma meandrense & Asia: Büyük Menderes River basin, western Anatolia, Turkey & Freshwater \\
\hline Chondrostoma phoxinus & $\begin{array}{l}\text { Europe: Croatia (Cetina drainage) and Bosnia-Herzegovina } \\
\text { (Glamocko, Livansjko and Duvanjsko poljes) }\end{array}$ & Freshwater \\
\hline Chondrostoma scodrense & Europe: Lake Skadar basin (Montenegro and Albania) & Freshwater \\
\hline Chromis pelloura & $\begin{array}{l}\text { Western Indian Ocean: restricted to the northern Gulf of Aqaba, } \\
\text { Red Sea. Possibly threatened }\end{array}$ & Marine \\
\hline Chuanchia labiosa & Asia: upper reaches of the Yellow River, China & Freshwater \\
\hline Clarias batrachus & $\begin{array}{l}\text { Asia: Java, Indonesia. Clarias aff. batrachus from Indochina and } \\
\text { Clarias aff }\end{array}$ & Freshwater, brackish \\
\hline Clarias cavernicola & $\begin{array}{l}\text { Africa: known only from the type locality, Aigumas Cave, North } \\
\text { Otavi, Namibia. Major threat is depletion of ground water }\end{array}$ & Freshwater \\
\hline Clarias dussumieri dussumieri & Asia: Goa, Karnataka, Kerala and Pondicherry in India & Freshwater \\
\hline Clinus spatulatus & $\begin{array}{l}\text { Southeast Atlantic: Bot River and Kleinmond estuary in the } \\
\text { southwestern Cape Province of South Africa }\end{array}$ & Brackish \\
\hline Cobitis calderoni & $\begin{array}{l}\text { Europe: Iberian Peninsula, in Ebro and Douro drainages, and } \\
\text { in some northeastern headwaters of Tagus }\end{array}$ & Freshwater \\
\hline Cobitis linea & Asia: endemic to River Kor, Gulf Coast in Iran & Freshwater \\
\hline Cobitis narentana & $\begin{array}{l}\text { Europe: Neretva and Trebisnjica drainages in Croatia and } \\
\text { Bosnia-Herzegovin }\end{array}$ & Freshwater \\
\hline Cobitis paludica & $\begin{array}{l}\text { Europe: Iberian Peninsula, except in Alagon system (Tagus } \\
\text { drainage), northern Ebro and northern Douro drainages }\end{array}$ & Freshwater \\
\hline Cobitis puncticulata & $\begin{array}{l}\text { Europe and Asia: Lower Maritza drainage in Greece. Lakes } \\
\text { Manyas and Ulubat drainages in Turkey }\end{array}$ & Freshwater \\
\hline Coreius septentrionalis & Asia: Huanghe River, China & Freshwater \\
\hline Cranoglanis bouderius & Asia: Kwangsi-Province in China & Freshwater \\
\hline Craterocephalus fluviatilis & Oceania: Australia. & Freshwater \\
\hline Crenicichla jupiaensis & South America: upper Paraná River basin, Brazil & Freshwater \\
\hline Crystallaria cincotta & $\begin{array}{l}\text { North America: Cumberland, Elk, Green and Muskingum river } \\
\text { drainages of the Ohio River basin, USA }\end{array}$ & Freshwater \\
\hline Cyprinella caerulea & $\begin{array}{l}\text { North America: Coosa and Cahaba River systems from southeast } \\
\text { Tennessee, northwest Georgia to Alabama, USA. Possibly } \\
\text { extirpated from Cahaba River system }\end{array}$ & Freshwater \\
\hline Cyprinella monacha & $\begin{array}{l}\text { North America: Historically in much of Tennessee River drainage, } \\
\text { from Virginia, North Carolina, Tennessee, Georgia to Alabama. } \\
\text { Recently have been observed only in Little Tennessee River, North } \\
\text { Carolina; Duck and Emory Rivers, Tennessee; and North Fork } \\
\text { Holston River, Virginia and Tennessee, USA }\end{array}$ & Freshwater \\
\hline Cyprinella proserpina & $\begin{array}{l}\text { North America: Devils River, lower Pecos River and nearby } \\
\text { tributaries of Rio Grande in Texas, USA. Also found in Rio San } \\
\text { Carlo (Rio Grande drainage), Coahuila, Mexico }\end{array}$ & Freshwater \\
\hline Cyprinodon atrorus & Central America: Río Salado and Cuatro Ciénegas systems in Mexico & Freshwater \\
\hline Cyprinodon bifasciatus & Central America: Cuatro Ciénegas system, Mexico & Freshwater \\
\hline
\end{tabular}


Table 1 (continued)

\begin{tabular}{|c|c|c|}
\hline Species & Distribution & Environment \\
\hline Cyprinodon bovinus & $\begin{array}{l}\text { North America: known only from Leon Creek (in Pecos River } \\
\text { system), Pecos County in Texas, USA }\end{array}$ & Freshwater \\
\hline Cyprinodon diabolis & $\begin{array}{l}\text { North America: restricted to Devils Hole, Ash Meadows in } \\
\text { Nye County, Nevada, USA }\end{array}$ & Freshwater \\
\hline Cyprinodon elegans & $\begin{array}{l}\text { North America: restricted to Toyah Creek and the effluents } \\
\text { (including irrigation canals) of San Solomon, Phantom Cave } \\
\text { and Griffin springs in Reeves County in Texas, USA }\end{array}$ & Freshwater \\
\hline Cyprinodon eximius & $\begin{array}{l}\text { North America: Rio Grande drainage in Texas in the USA, } \\
\text { from Devils River to mouth of Rio Conchos. Also in Rio } \\
\text { Conchos system and endorheic Rio Sauz basin in Mexico }\end{array}$ & Freshwater \\
\hline Cyprinodon laciniatus & $\begin{array}{l}\text { Central America: known only from the lakes on New Providence } \\
\text { Island, Great Bahama Bank }\end{array}$ & Freshwater \\
\hline Cyprinodon pecosensis & North America: Pecos River system in Texas and New Mexico, USA & Freshwater \\
\hline Cyprinodon radiosus & $\begin{array}{l}\text { North America: found only in Owens Valley in southern California, } \\
\text { USA }\end{array}$ & Freshwater \\
\hline Cyprinodon tularosa & North America: found only in Tularosa Valley in New Mexico, USA & Freshwater \\
\hline Cyprinus ilishaestomus & Asia: Qiluhu Lake in Yunnan, China & Freshwater \\
\hline Cyprinus micristius & Asia: Dian chi Lake, Yunnan, China & Freshwater \\
\hline Cyprinus pellegrini & Asia: China & Freshwater \\
\hline Cyprinus pellegrini pellegrini & Asia: China & Freshwater \\
\hline Cyprinus qionghaiensis & Asia: China & Freshwater \\
\hline Deltistes luxatus & $\begin{array}{l}\text { North America: Lost River system (upper Klamath River basin) in } \\
\text { Oregon and California, USA }\end{array}$ & Freshwater \\
\hline Delturus parahybae & South America: Paraíba do Sul River basin & Freshwater \\
\hline Dionda diaboli & $\begin{array}{l}\text { North America: Devils River and nearby San Felipe, Sycamore and } \\
\text { Las Moras Creeks, Val Verde and Kinney counties in Texas, USA }\end{array}$ & Freshwater \\
\hline Diplomystes camposensis & South America: Valdivia region, southern Chile & Freshwater \\
\hline Elassoma alabamae & $\begin{array}{l}\text { North America: endemic to Moss Spring and (historically) adjacent } \\
\text { springs in the middle Tennessee River drainage in Alabama, USA }\end{array}$ & Freshwater \\
\hline Elassoma boehlkei & $\begin{array}{l}\text { North America: Waccamaw and Santee River drainages in North } \\
\text { Carolina and South Carolina, USA }\end{array}$ & Freshwater \\
\hline Elassoma okatie & $\begin{array}{l}\text { North America: Edisto and Savannah River drainages in South } \\
\text { Carolina, USA }\end{array}$ & Freshwater \\
\hline Empetrichthys latos & $\begin{array}{l}\text { North America: restricted to three springs in Pahrump Valley, } \\
\text { Nye County in Nevada, USA where it was the only native fish. } \\
\text { Now exists only outside Pahrump Valley, where it was transplanted } \\
\text { to prevent its extinction }\end{array}$ & Freshwater \\
\hline Epinephelus itajara & $\begin{array}{l}\text { Western Atlantic: Florida, USA to southern Brazil, including the } \\
\text { Gulf of Mexico and the Caribbean. Eastern Atlantic: Senegal to } \\
\text { Congo (reported as Epinephelus esonue); rare in Canary Islands }\end{array}$ & Marine, brackish \\
\hline Epinephelus marginatus & $\begin{array}{l}\text { East and Southwest Atlantic and Western Indian Ocean: East Atlantic: } \\
\text { throughout the Mediterranean Sea, and from the southern Bay of } \\
\text { Biscaye to southern tip of Africa. Stray specimens reported from } \\
\text { the British Isles. Southwest Atlantic: southeastern Brazil, Uruguay, } \\
\text { and Argentina. Western Indian Ocean: from tip of Africa to southern } \\
\text { Mozambique and southern Madagascar. Reported from Oman }\end{array}$ & Marine \\
\hline Epinephelus striatus & $\begin{array}{l}\text { Western Atlantic: Bermuda, Florida, Bahamas, Yucatan Peninsula } \\
\text { and throughout the Caribbean to southern Brazil. Not known from } \\
\text { the Gulf of Mexico except at the Campeche Bank off the coast of } \\
\text { Yucatan, at Tortugas and off Key West }\end{array}$ & Marine \\
\hline Eremichthys acro & $\begin{array}{l}\text { North America: found in the warm springs of Soldier Meadows, } \\
\text { Lahontan basin, Humboldt County in Nevada, USA }\end{array}$ & Freshwater \\
\hline Etheostoma chermocki & North America: Mobile Bay ecoregion, USA & Freshwater \\
\hline
\end{tabular}


Table 1 (continued)

\begin{tabular}{|c|c|c|}
\hline Species & Distribution & Environment \\
\hline Etheostoma chienense & North America: USA & Freshwater \\
\hline Etheostoma cinereum & $\begin{array}{l}\text { North America: found only in Cumberland and Tennessee River } \\
\text { drainages in Virginia, Kentucky, Tennessee, Georgia and } \\
\text { Alabama, USA }\end{array}$ & Freshwater \\
\hline Etheostoma fonticola & $\begin{array}{l}\text { North America: found only in San Marcos and Comal springs } \\
\text { and their effluent rivers (Guadalupe River system) in southern } \\
\text { central Texas, USA }\end{array}$ & Freshwater \\
\hline Etheostoma forbesi & North America: Cumberland ecoregion, USA & Freshwater \\
\hline Etheostoma lugoi & $\begin{array}{l}\text { Central America: Rio Mesquites and its tributaries in Bolson } \\
\text { de Cuatro Cienegas, Mexico }\end{array}$ & Freshwater \\
\hline Etheostoma nianguae & $\begin{array}{l}\text { North America: found only in Osage River drainage (Missouri } \\
\text { River basin) in southern central Missouri, USA }\end{array}$ & Freshwater \\
\hline Etheostoma percnurum & North America: Cumberland and Tennessee ecoregions, USA & Freshwater \\
\hline \multicolumn{3}{|l|}{ Etheostoma perlongum } \\
\hline Etheostoma segrex & $\begin{array}{l}\text { Central America: upper Rio Salado de los Nadadores in Bolson } \\
\text { de Cuatro Ciénegas, Coahuila, Mexico }\end{array}$ & Freshwater \\
\hline Etheostoma sellare & $\begin{array}{l}\text { North America: tributaries of lower Susquehanna River, Harford } \\
\text { County in Maryland, USA }\end{array}$ & Freshwater \\
\hline Eucyclogobius newberryi & $\begin{array}{l}\text { Eastern Pacific: Del Norte County in northern California, USA } \\
\text { to Del Mar in southern California }\end{array}$ & Marine, brackish \\
\hline Fundulus lima & Central America: Mexico & Freshwater \\
\hline Fundulus waccamensis & $\begin{array}{l}\text { North America: Lake Waccamaw in Columbus County in North } \\
\text { Carolina, USA }\end{array}$ & Freshwater \\
\hline Galaxias argenteus & Southwest Pacific: endemic to New Zealand & Amphidromous \\
\hline Galaxias auratus & $\begin{array}{l}\text { Oceania: known only from Central Plateau of Tasmania in Lake } \\
\text { Sorell, Lake Crescent, a tributary of Lake Crescent at Interlaken, } \\
\text { and Clyde River, which is the outflow of Lake Crescent }\end{array}$ & Freshwater \\
\hline Galaxias cobitinis & Oceania: New Zealand & Freshwater \\
\hline Galaxias fontanus & $\begin{array}{l}\text { Oceania: known only from the upper Swan River of eastern } \\
\text { Tasmania }\end{array}$ & Freshwater \\
\hline Galaxias fuscus & Oceania: endemic to Australia & Freshwater \\
\hline Galaxias gracilis & $\begin{array}{l}\text { Oceania: endemic to New Zealand. Exterminated in part of } \\
\text { its range by introduced trout }\end{array}$ & Freshwater \\
\hline Galaxias johnstoni & $\begin{array}{l}\text { Oceania: known only in Clarence Lagoon and tributaries and the } \\
\text { upper reaches of the Clarence River, which is part of the Derwent } \\
\text { River system of Tasmania, Australia }\end{array}$ & Freshwater \\
\hline Galaxias neocaledonicus & Oceania: New Caledonia & Freshwater \\
\hline Galaxias pedderensis & $\begin{array}{l}\text { Oceania: known only from Lake Pedder and Lake Gordon in } \\
\text { southern Tasmania, Australia }\end{array}$ & Freshwater \\
\hline Galaxiella munda & $\begin{array}{l}\text { Oceania: endemic to Australia. Known only from the southwestern } \\
\text { part in coastal streams between Albany and Ellen Brook }\end{array}$ & Freshwater \\
\hline Galaxiella nigrostriata & Eastern Indian Ocean: Western Australia & Freshwater \\
\hline Galaxiella pusilla & $\begin{array}{l}\text { Oceania: Australia; coastal streams of Victoria from the Mitchell } \\
\text { River or a little to the east, west to Mount Gambier in South } \\
\text { Australia and south to the northeastern corner of Tasmania, } \\
\text { including Flinders Island in Bass Strait }\end{array}$ & Freshwater \\
\hline Gambusia amistadensis & $\begin{array}{l}\text { North America: formerly in Goodenough Spring (Rio Grande } \\
\text { drainage) in Texas, USA }\end{array}$ & Freshwater \\
\hline Gambusia eurystoma & Central America: Grijalva system, Mexico & Freshwater \\
\hline Gambusia gaigei & $\begin{array}{l}\text { North America: formerly found in Boquillas and Graham Ranch } \\
\text { springs, Brewster County in Texas; now restricted to an artificial } \\
\text { spring-fed pond in Big Bend National Park in Texas, USA }\end{array}$ & Freshwater \\
\hline
\end{tabular}


Table 1 (continued)

\begin{tabular}{|c|c|c|}
\hline Species & Distribution & Environment \\
\hline Gambusia georgei & $\begin{array}{l}\text { North America: formerly in San Marcos Spring and River in } \\
\text { Texas, USA }\end{array}$ & Freshwater \\
\hline Gambusia heterochir & $\begin{array}{l}\text { North America: Headwater springs of Clear Creek (in San Saba } \\
\text { River system), Menard County in Texas, USA }\end{array}$ & Freshwater \\
\hline Gambusia nobilis & $\begin{array}{l}\text { North America: found only in Pecos River system in New Mexico } \\
\text { and Texas, USA }\end{array}$ & Freshwater \\
\hline Gila boraxobius & $\begin{array}{l}\text { North America: Borax Lake (in Alvord basin), Harney County in } \\
\text { Oregon, USA }\end{array}$ & Freshwater \\
\hline Gila elegans & $\begin{array}{l}\text { North America: Colorado River drainage in Wyoming, Colorado, } \\
\text { Utah, New Mexico, Arizona and California in USA, and Mexico. } \\
\text { Extant only in Green River in Utah and perhaps in some large } \\
\text { impoundments of the Colorado River }\end{array}$ & Potamodromous \\
\hline Girardinichthys viviparus & Central America: Mexico & Freshwater \\
\hline \multicolumn{3}{|l|}{ Glyphis } \\
\hline Glyphis gangeticus & $\begin{array}{l}\text { Indo-West Pacific: Hooghly River, Ganges system, West Bengal, } \\
\text { India, and likely from the vicinity of Karachi, Pakistan. Reported } \\
\text { from Taiwan }\end{array}$ & Amphidromous \\
\hline Gobio benacensis & $\begin{array}{l}\text { Europe: Italy and Slovenia from Po to Soca and Reka drainages. } \\
\text { Occurrence elsewhere in northern Adriatic basin is possible. } \\
\text { Introduced to central and southern Italy }\end{array}$ & Freshwater \\
\hline Gobio uranoscopus & Europe: Danube drainage & Freshwater \\
\hline Gobiocypris rarus & $\begin{array}{l}\text { Asia: Liusha river, tributary of the Dadu river at Jiuxiang, Hanyuan } \\
\text { County, Sichuan Province, China }\end{array}$ & Freshwater \\
\hline Gymnocharacinus bergi & $\begin{array}{l}\text { South America: Valcheta stream in Rio Negro basin, Southern } \\
\text { Argentina }\end{array}$ & Freshwater \\
\hline Gymnocypris przewalskii & Asia: China & Freshwater \\
\hline Hemigrammocapoeta kemali & Asia: Turkey & Freshwater \\
\hline Hemisalanx prognathus & Northwest Pacific & $\begin{array}{l}\text { Marine; freshwater; } \\
\text { brackish }\end{array}$ \\
\hline Henochilus wheatlandii & South America: Mucuri and Doce River basins in Brazil & Freshwater \\
\hline Herichthys labridens & $\begin{array}{l}\text { North America: Atlantic slope, in the Panuco River basin, } \\
\text { Mexico }\end{array}$ & Freshwater \\
\hline Heteropneustes fossilis & Asia: Pakistan and Sri Lanka to Myanmar & Freshwater, brackish \\
\hline Hippocampus capensis & Southeast Atlantic: endemic to South Africa & Marine, brackish \\
\hline Hippocampus comes & $\begin{array}{l}\text { Western Central Pacific: Malaysia, Singapore, Viet Nam and } \\
\text { Philippines }\end{array}$ & Marine \\
\hline Hippocampus erectus & $\begin{array}{l}\text { Western Atlantic: Nova Scotia, Canada and northern Gulf of } \\
\text { Mexico to Panama and Venezuela. A southern form that may } \\
\text { prove to be a separate species is known from Rio de Janeiro, } \\
\text { Brazil and questionably from Suriname }\end{array}$ & Marine \\
\hline Hippocampus reid & Western Atlantic: North Carolina in USA, Bermuda & Marine \\
\hline Hippocampus spinosissimus & ndo-Pacific: Sri Lanka to Taiwan and Australia & Marine, brackish \\
\hline Holacanthus passer & $\begin{array}{l}\text { Eastern Pacific: Gulf of California to Peru, including the } \\
\text { Galapagos Islands }\end{array}$ & Marine \\
\hline Horabagrus brachysoma & Asia: Kerala, India & Freshwater, brackish \\
\hline Horabagrus nigricollaris & Asia: Chalakudy River in Kerala, India & Freshwater \\
\hline \multicolumn{3}{|l|}{ Hubbsinna turneri } \\
\hline Hucho bleeker & Asia: China & Freshwater \\
\hline Hucho hucho & $\begin{array}{l}\text { Europe: Danube drainage. Introduced into other European river } \\
\text { basins when their numbers declined due to ecological changes } \\
\text { in the Danube }\end{array}$ & Freshwater \\
\hline
\end{tabular}


Table 1 (continued)

\begin{tabular}{|c|c|c|}
\hline Species & Distribution & Environment \\
\hline Huso huso & Eurasia: Caspian, Black, Azov and Adriatic Sea basins & Anadromous \\
\hline Hypseleotris dayi & $\begin{array}{l}\text { Africa. Asia: Reported from Palau, the Ryukyu Islands, the } \\
\text { Philippines Indonesia, New-Guinea, New Caledonia, the } \\
\text { Vanuatu, Fiji and Samoa, up to La Réunion, Comoros, and } \\
\text { Madagascar }\end{array}$ & $\begin{array}{l}\text { Marine; freshwater; } \\
\text { brackish; }\end{array}$ \\
\hline Iberochondrostoma lusitanicum & $\begin{array}{l}\text { Europe: Portugal in Sado, Lizandro, Samarra, Colares and Ossos } \\
\text { drainages, south bank tributaries of Tagus }\end{array}$ & Freshwater \\
\hline Iberocypris palaciosi & Europe: middle Guadalquivir drainage near Andújar in Spain & Freshwater \\
\hline Iotichthys phlegethontis & North America: Bonneville basin in northern Utah, USA & Freshwater \\
\hline Iranocypris typhlops & Asia: endemic to the River Tigris, Iran & Freshwater \\
\hline Labeo seeberi & $\begin{array}{l}\text { Africa: within the drainage basin of the Olifants River, Limpopo } \\
\text { system, Transvaal, South Africa }\end{array}$ & Potamodromous \\
\hline Ladigesocypris ghigii & Europe: Rhodos Island in Greece & Freshwater \\
\hline Latimeria chalumnae & $\begin{array}{l}\text { Indian Ocean: well known population off the islands of Grand } \\
\text { Comoro and Anjouan in the Comoros. Other populations in } \\
\text { South Africa, Madagascar, and Mozambique. Likely to occur } \\
\text { as strays at islands like Astove and Cosmoledo }\end{array}$ & Marine \\
\hline Lebias ginaonis & Asia: Iran & Freshwater \\
\hline Lefua echigonia & Asia: Japan & Freshwater \\
\hline Lentipes concolor & Oceania: known only from Hawaii & $\begin{array}{l}\text { Marine; freshwater; } \\
\text { brackish }\end{array}$ \\
\hline Lepidogalaxias salamandroides & $\begin{array}{l}\text { Oceania: endemic to Western Australia in seasonal pools } \\
\text { between the Blackwood and Kent rivers }\end{array}$ & Freshwater \\
\hline Lepidomeda vittata & $\begin{array}{l}\text { North America: upper Little Colorado River system in } \\
\text { eastern Arizona, USA }\end{array}$ & Freshwater \\
\hline Leptobotia elongata & Asia: middle and upper reaches of the Yangtze River, China & Freshwater \\
\hline Leuciscus carolitertii & $\begin{array}{l}\text { Europe: Iberian Peninsula in Douro, Mondego, Umia, Limia, } \\
\text { Tagus, Miño and Lérez drainages }\end{array}$ & Freshwater \\
\hline Leuciscus keadicus & Europe: endemic to the Evrotas River in Peloponnesus, Greece & Freshwater \\
\hline Leuciscus lucumonis & $\begin{array}{l}\text { Europe: Serchio, Ombrone, Arno and Tevere drainages } \\
\text { (Tyrrhenian slope) in Italy }\end{array}$ & Freshwater \\
\hline Liobagrus kingi & Asia: Yunnan, China & Freshwater \\
\hline \multicolumn{3}{|l|}{ Luciobarbus subquincunciatus } \\
\hline Luciobrama macrocephalus & Asia: China and Vietnam & Freshwater, brackish \\
\hline Maccullochella ikei & Oceania: Australia & Freshwater \\
\hline Maccullochella macquariensis & $\begin{array}{l}\text { Oceania: Murray-Darling basin, New South Wales, Australia-Mitta } \\
\text { Mitta River, upper Murray River (Tintaldra, Mulwala area), } \\
\text { Murrumbidgee River, Cataract Dam (Nepean River), also in } \\
\text { the Macquarie River. Stocked population in Seven Creeks River } \\
\text { and Glenbawm Dam (Hunter River); also in Lake Sambell }\end{array}$ & Freshwater \\
\hline Macquaria australasica & $\begin{array}{l}\text { Oceania: Once widely distributed in the Murray-Darling basin and } \\
\text { southeastern coastal drainages. Now reduced to cooler upper reaches } \\
\text { of Murray-Darling basin, New South Wales, Australia. Introduced } \\
\text { in the Wannon, Barwon, Yarra Rivers (Victoria) and the Nepean and } \\
\text { Shoalhaven Rivers (New South Wales), Australia }\end{array}$ & Potamodromous \\
\hline Macropleurodus bicolor & Africa: Lake Victoria & Freshwater \\
\hline Macropodus hongkongensis & Asia: Hong Kong & Freshwater \\
\hline Macrura reevesi & $\begin{array}{l}\text { Northwest Pacific: China and possibly southward into South China } \\
\text { Sea, but records uncertain. Eastern Indian Ocean: two specimens } \\
\text { collected from Phuket Island, Andaman Sea }\end{array}$ & $\begin{array}{l}\text { Marine; freshwater; } \\
\text { brackish }\end{array}$ \\
\hline Meda fulgida & North America: Gila River system in Arizona and New Mexico, USA & Freshwater \\
\hline
\end{tabular}


Table 1 (continued)

\begin{tabular}{|c|c|c|}
\hline Species & Distribution & Environment \\
\hline Menidia extensa & $\begin{array}{l}\text { North America: occurs only in the Lake Waccamaw in North } \\
\text { Carolina, USA }\end{array}$ & Freshwater \\
\hline \multicolumn{3}{|l|}{ Menidia riojai } \\
\hline Merluccius hubbsi & $\begin{array}{l}\text { Southwest Atlantic: off southern Brazil to Argentina and the Falkland } \\
\text { Islands }\end{array}$ & Marine \\
\hline Micropterus treculii & $\begin{array}{l}\text { North America: found only on Edwards Plateau in Brazos, Colorado, } \\
\text { Guadalupe, San Antonio and upper Nueces }\end{array}$ & Freshwater \\
\hline Milyeringa veritas & $\begin{array}{l}\text { Australia: subterranean waters below the narrow coastal plain } \\
\text { between North West Cape and Yardie Creek; Five Mile, } \\
\text { Homestead, Kudmurra, Milyering (Mangrove), New Yardie, } \\
\text { Pilgramuna and Tantabiddi Wells. }\end{array}$ & Freshwater \\
\hline Misgurnus fossilis & $\begin{array}{l}\text { Europe and Asia: In Europe, north of the Alps, from Meuse eastward } \\
\text { to Neva drainages and Lake Ladoga; northern Black Sea basin } \\
\text { from Danube eastward to Kuban, absent on the southern section; } \\
\text { Caspian basin in Volga and Ural drainages. Not native to Great } \\
\text { Britain, Scandinavia, Apennine and Iberian peninsulas, Crimea, } \\
\text { and Adriatic, Aegean and White Sea basins. Locally introduced } \\
\text { in Rhône drainage (France) and perhaps elsewhere }\end{array}$ & Freshwater \\
\hline Moapa coriacea & $\begin{array}{l}\text { North America: endemic to headwaters of Moapa River, Clark County } \\
\text { in southeastern Nevada, USA. Subject to major population } \\
\text { fluctuations and varies from rare to common within extremely } \\
\text { restricted range }\end{array}$ & Freshwater \\
\hline Moxostoma congestum & North America: USA; occurrence in Mexico is uncertain & Freshwater \\
\hline Mycteroperca bonaci & $\begin{array}{l}\text { Western Atlantic: Bermuda and Massachusetts, USA to southern } \\
\text { Brazil, including the southern Gulf of Mexico and the Caribbean. } \\
\text { Adults are unknown from the northeastern coast of the USA }\end{array}$ & Marine \\
\hline Mycteroperca microlepis & $\begin{array}{l}\text { Western Atlantic: North Carolina, USA (with juveniles occurring } \\
\text { as far north as Massachusetts) to the Yucatan Peninsula, Mexico. } \\
\text { Rare in Bermuda }\end{array}$ & Marine, brackish \\
\hline Myxocyprinus asiaticus & Asia: China & Freshwater \\
\hline Nannatherina balstoni & Oceania: coastal drainages of southwest Australia & Freshwater \\
\hline Nannoperca oxleyana & $\begin{array}{l}\text { Oceania: endemic in the coastal drainages of northeast and } \\
\text { southeast Australia, from Noosa River to Richmond River }\end{array}$ & Freshwater \\
\hline Neoceratodus forsteri & $\begin{array}{l}\text { Oceania: southern Queensland, Australia in Burnett and Mary } \\
\text { River systems }\end{array}$ & Freshwater \\
\hline Neochanna burrowsius & Oceania: endemic to New Zealand & Freshwater \\
\hline Neosalanx reganius & Asia: Ariake Sea, Kyushu Island, Japan & $\begin{array}{l}\text { Marine; freshwater; } \\
\text { brackish }\end{array}$ \\
\hline Notropis albizonatus & $\begin{array}{l}\text { North America: Known only from one small stream each in the } \\
\text { Cumberland River drainage (Little South Fork, Kentucky) } \\
\text { and Tennessee River drainage (Paint Rock River, Alabama), USA }\end{array}$ & Freshwater \\
\hline Notropis bifrenatus & $\begin{array}{l}\text { North America: St. Lawrence-Lake Ontario drainage in Quebec } \\
\text { and Ontario in Canada, and New York in the USA; Atlantic Slope } \\
\text { drainages from southern Maine, USA to Roanoke River system } \\
\text { in southern Virginia, USA; isolated population in lower Neuse } \\
\text { River drainage in eastern North Carolina, USA }\end{array}$ & Freshwater \\
\hline Notropis boucardi & North America: Mexico & Freshwater \\
\hline Notropis girardi & $\begin{array}{l}\text { North America: Arkansas River drainages from western Arkansas } \\
\text { to western Kansas, western Oklahoma, Texas and northeastern } \\
\text { New Mexico, USA. }\end{array}$ & Freshwater \\
\hline Notropis sabinae & $\begin{array}{l}\text { North America: St. Francis and lower White (including lower Black) } \\
\text { River drainages in Missouri and Arkansas, USA; Little River } \\
\text { system (lower Red River drainage), Louisiana, USA; and Gulf } \\
\text { Coast drainages from Calcasieu River in Louisiana to San Jacinto } \\
\text { River in Texas, USA }\end{array}$ & Freshwater \\
\hline
\end{tabular}


Table 1 (continued)

\begin{tabular}{|c|c|c|}
\hline Species & Distribution & Environment \\
\hline Notropis simus pecosensis & $\begin{array}{l}\text { North America: Found in the upper Rio Grande (above El Paso, } \\
\text { Texas), Texas and New Mexico and in the Pecos River, New } \\
\text { Mexico, USA }\end{array}$ & Freshwater \\
\hline Notropis topeka & $\begin{array}{l}\text { North America: Mississippi River basin in the USA from southern } \\
\text { Minnesota and southeastern South Dakota south to central Missouri } \\
\text { and southern Kansas (in Arkansas River drainage) }\end{array}$ & Freshwater \\
\hline Noturus munitus & $\begin{array}{l}\text { North America: Gulf Slope drainages in the USA: disjunct populations } \\
\text { in Conasauga River, Tennessee; Etowah River, Georgia; Cahaba } \\
\text { River, central Alabama; Tombigbee River in western Alabama } \\
\text { and eastern Mississippi; and Pearl River in southern Mississippi and } \\
\text { eastern Louisiana }\end{array}$ & Freshwater \\
\hline Noturus placidus & $\begin{array}{l}\text { North America: Arkansas River drainage in USA: Spring River in } \\
\text { southwestern Missouri and southeastern Kansas; Cottonwood and } \\
\text { Neosho rivers in eastern Kansas and northeastern Oklahoma; lower } \\
\text { few miles of Illinois River in eastern central Oklahoma }\end{array}$ & Freshwater \\
\hline Odontobutis yaluensis & Asia: China & Freshwater \\
\hline Ogilbia pearsei & Central America: Yucatan Peninsula, Mexico & Freshwater \\
\hline Oligosarcus schindleri & $\begin{array}{l}\text { South America: Chapare River basin and lagoons near Cochabamba, } \\
\text { Bolivia }\end{array}$ & Freshwater \\
\hline Oncorhynchus iwame & Asia: Japan & Freshwater \\
\hline $\begin{array}{l}\text { Oncorhynchus masou } \\
\text { formosanus }\end{array}$ & Asia: endemic to Taiwan & Freshwater \\
\hline Oncorhynchus mykiss nelsoni & $\begin{array}{l}\text { Native to Pacific Slope from Kuskokwim River, Alaska to } \\
\text { (at least) Rio Santa Domingo, Baja California, Mexico; } \\
\text { upper Mackenzie River drainage (Arctic basin), Alberta and } \\
\text { British Columbia in Canada; endorheic basins of southern } \\
\text { Oregon, USA. Widely introduced in cold waters elsewhere in } \\
\text { North America and rest of the world }\end{array}$ & Anadromous \\
\hline Onychostoma alticorpus & Asia: Taiwan and China] & Freshwater \\
\hline Ophiogobius jenynsi & Southeast Pacific: Chile & Marine \\
\hline Ophisternon candidum & Oceania: Western Australia & Potamodromous \\
\hline Ophisternon infernale & Central America: Yucatan, Mexico & Freshwater \\
\hline Opsaridium microlepis & Africa: Endemic to Lake Malawi. & Potamodromous \\
\hline Oregonichthys crameri & $\begin{array}{l}\text { North America: Willamette and Umpqua River drainages in } \\
\text { Oregon, USA. Common in Umpqua but localized and rare } \\
\text { in Willamette because of habitat alteration }\end{array}$ & Freshwater \\
\hline Orestias ascotanensis & South America: Ascotán Lake, Chile & Freshwater \\
\hline Ossubtus xinguense & South America: Xingu River basin in Brazil & Freshwater \\
\hline Oxygymnocypris stewartii & Asia: Brahmaputra River in Tibet & Freshwater \\
\hline Pangasianodon gigas & $\begin{array}{l}\text { Asia: endemic to the Mekong basin where it has become rare } \\
\text { due to overexploitation }\end{array}$ & Potamodromous \\
\hline Pangasius pangasius & Asia: large rivers of Indian subcontinent and Myanmar & Freshwater, brackish \\
\hline Pangasius sanitwongsei & Asia: Chao Phraya and Mekong basins & Freshwater \\
\hline Papillogobius punctatus & $\begin{array}{l}\text { Eastern Indian Ocean: Known only from the Swan Estuary in } \\
\text { Western Australia }\end{array}$ & Marine, brackish \\
\hline Parachondrostoma turiense & Europe: river basins of Turia and Mijares in eastern Spain & Freshwater \\
\hline Paracobitis smithi & $\begin{array}{l}\text { Asia: Baq-e-Loveh pool, Ab-i-Serum Valley near Tang-e-haft } \\
\text { railway station, Zagros mountains, Ira }\end{array}$ & Freshwater \\
\hline Pareiorhaphis garbe & $\begin{array}{l}\text { South America: Brazil in the rivers of the southern drainage of } \\
\text { the serra dos Orgaos, Macaé and Macacú rivers }\end{array}$ & Freshwater \\
\hline Percilia irwini & $\begin{array}{l}\text { South America: Chile in streams and rivers of Malleco and } \\
\text { Bio-Bio River basins }\end{array}$ & Freshwater \\
\hline Percina aurolineata & & Freshwater \\
\hline
\end{tabular}


Table 1 (continued)

\begin{tabular}{l} 
Species \\
\hline \\
Percina bimaculata \\
Percina pantherina \\
Percina rex \\
Phallotorynus jucundus \\
Phoxinellus epiroticus \\
Phoxinus cumberlandensis \\
Pimelodella kronei \\
Plagopterus argentissimus \\
Plesiomyzon baotingensis \\
Poblana alchichica \\
Poecilia latipunctata \\
Poecilia sulphuraria \\
Polysteganus undulosus \\
Pristis microdon
\end{tabular}

Pristis pectinata

Probarbus jullieni

Procypris rabaud

Profundulus hildebrandi

Protogobius attiti

Protomyzon pachychilus

Prototroctes oxyrhynchus

Psephurus gladius

Pseudobagrus medianalis

Pseudobarbus burgi

Pseudobarbus phlegethon
Distribution

Environment

North America: Coosa and Cahaba River systems (in Mobile

Bay drainage) in Georgia and Alabama, USA

North America: Chesapeake Bay drainages, USA

North America: Little River system (in Red River drainage) of southwestern Arkansas and southeastern Oklahoma in the USA

North America: upper Roanoke, upper Dan and upper Chowan River systems (in Roanoke River drainage) in Virginia, USA

South America: Grande River drainage

Europe: Lake Pamvotis in Greece

North America: upper Cumberland River drainage (above Big South Fork) in Kentucky and Tennessee, USA

South America: caves in the Ribeira do Iguape River basin in Sao Paulo, Brazil

North America: Virgin and Gila River systems (both lower Colorado River drainage) in Utah, Nevada and Arizona, USA. Now believed extirpated in Gila River system

Asia: endemic to the drainages in Hainan Island, China

Central America: Mexico

North and Central America: Rio Panuco basin in Tamaulipas, Mexico

Central America: Grijalva system in Mexico

Western Indian Ocean: southern Mozambique to Durban, South Africa Europe: Adriatic coasts, from Po delta (Italy) to Neretva (Croatia)

Indo-West Pacific: East Africa to New Guinea, north to the Philippines and Viet Nam, south to Australia. Also Atlantic and eastern Pacific if Pristis perotteti and Pristis zephyreus are synonymized with this species. The original description of Pristis microdon did not give a locality, but most authors have used the name Pristis microdon for the Indo-West Pacific sawfishes of this species group as contrasted from the Atlantic Pristis perotteti and the eastern Pacific Pristis zephyreus.

Circumglobal. Western Atlantic: North Carolina (USA), Bermuda and northern Gulf of Mexico to Argentina. Caribbean, rare in Bermuda. Eastern Atlantic: Gibraltar to Namibia; possibly in the Mediterranean Sea. Indo-West Pacific: Red Sea and East Africa to the Philippines. Possibly occurring in the eastern Pacific

Asia: Mekong, Chao Phraya and Meklong basins of Indo-China and Thailand, and the Pahang and Perak basins of Malaysia

Asia: middle and upper reaches of Yangtze River, China

Central America: San Cristóbal de las Casas valley in Chiapas, Mexico

Oceania: New Caledonia

Asia: China

Oceania: endemic to New Zealand

Asia: China, endemic to the Yangtze River and its tributaries

Asia: Dian Chi Lake, Yunnan, China

Africa: Occurs in the Berg River system and Verlorenvlei Rivers, southwest Cape. Probably extinct in the Eerste River, Cape Province, South Africa
Freshwater

Freshwater

Freshwater

Freshwater

Freshwater

Freshwater

Freshwater

Freshwater

Freshwater, brackish

Freshwater

Freshwater

Freshwater

Marine

Freshwater

Amphidromous

Amphidromous

Freshwater, brackish

Freshwater

Freshwater

Freshwater

Freshwater

Marine; freshwater; brackish

Freshwater

Freshwater

Freshwater

Freshwater 
Table 1 (continued)

\begin{tabular}{ll}
\hline Species & Distribution \\
\hline & Africa: tributaries of the Clanwilliam Olifants River, Cape \\
Province, South Africa & Africa: Headwater streams of the Orange River in Lesotho. \\
Type locality is the Umkomazana River in Natal, but not recorded \\
Pseudobarbus quathlambae & Nhere since the 1930s. Protected within the Sehlabathebe \\
& Oceania: southern Queensland around the vicinity of Brisbane, \\
& Australia northward along the coast, 300 km to Bundaberg area \\
Pseudomugil mellis & Asia: Turkey \\
Pseudophoxinus anatolicus & Asia: Tuz Gölü tributaries and the region of Aksaray and Nigde, \\
Pseudophoxinus crassus & central Anatolia, Turkey \\
Pseudophoxinus egridiri & Asia: endemic to Turkey \\
Pseudoplatystoma corruscans & South America: São Francisco and Paraná River basins
\end{tabular}

Pseudorasbora

South America: São Francisco and Paraná River basins

Environment

Pseudoscaphirhynchus spp.

Psilorhynchus homaloptera

Pterapogon kauderni

Ptychobarbus chungtienensis

Ptychocheilus lucius

Pungitius hellenicus

Pungu maclaren

Puntius denisonii

Puntius lindo

Puntius sarana

Puntius tumba

Rhincodon typus

Rhyacichthys guilberti

Romanichthys valsanicola

Asia: India, Myanmar and Nepal. Also reported from Tibet

Freshwater

Western Central Pacific: Apparently restricted to Banggai Islands, Indonesia. Threatened by extinction due to collection for the aquarium trade

Asia: Zhongdian, Yunnan, China

North America: Colorado River drainage in Wyoming, Colorado, Utah, New Mexico, Arizona, Nevada and California, USA and Mexico

Europe: lower Sperchios drainage in Greece

Freshwater, brackish

Freshwater, brackish

Freshwater

Freshwater

Freshwater

Freshwater

Freshwater

Marine

Freshwater

Potamodromous

Africa: endemic to Lake Barombi Mbo, west Cameroon

Asia: endemic to India

Asia: endemic to Lake Lanao, Mindanao, Philippines

Asia: Afghanistan, Pakistan, India, Nepal, Bangladesh, Bhutan

Asia: generally distributed over the Lanao Plateau, Mindanao, Philippines

Circumglobal in tropical and warm temperate seas. Western Atlantic: New York, USA through the Caribbean to central Brazil. Eastern Atlantic: Senegal to Gulf of Guinea; St. Paul's Rocks. Indian Ocean: throughout the region, including the Red Sea and the Persian Gulf. Western Pacific: Japan to Australia and Hawaii. Eastern Pacific: California, USA to Chile

Oceania

Amphidromous

Europe: Danube drainage in Romania; previously known from upper River Arges and its tributaries Vâlsan and Râul Doamnei. Today, restricted to $1 \mathrm{~km}$ of upper River Vâlsan upstream of Bradet village, but adjacent basins still insufficiently surveyed.

Salminus affinis

Salmo dentex

South America: Magdalena River basin and Santiago River basin in Ecuador

Europe: Croatia, Bosnia-Herzegovina, Montenegro, Albania, Greece, Freshwater

Salmo platycephalus Kosovo, Macedonia

Asia: Turkey

Freshwater

Europe: Restricted to southern Caspian basin

Salvelinus confluentus

Coastal and mountain streams of Arctic, Pacific, and Missouri River drainages from extreme southern Yukon in Canada to headwaters

Freshwater

Freshwater

Freshwater

Freshwater

Freshwater, brackish

Freshwater

Marine

Freshwater

Marine; freshwater; brackish

Marine; freshwater; brackish 
Table 1 (continued)

\begin{tabular}{llc}
\hline Species & Distribution & Environment \\
\hline & of Columbia River drainage in northern Nevada, USA, and McCloud & \\
& River drainage in northern California, USA \\
Asia: known only from the ancient Lake El'gygytgyn located in the & Freshwater \\
headwaters of the Enmyvaam River, Anadyr River catchment in & \\
central Chukotka, Russia & North America: most of eastern Canada from Newfoundland to western Marine; freshwater; \\
Salvelinus fontinalis & side of Hudson Bay; south in Atlantic, Great Lakes, and Mississippi & brackish \\
& River basins to Minnesota and northern Georgia in USA. & \\
& South America: Argentina. Widely introduced in temperate \\
& regions of other continents
\end{tabular}

Salvelinus leucomaenis japonicus

Salvethymus svetovidov

Sandelia bainsii

Scardinius scardafa

\section{Scaturiginichthys \\ vermeilipinnis \\ Schizothorax}

Schizothorax longibarbus

Schizothorax taliensis

Seminemacheilus tongiorgii

Sicyopterus sarasini

Silhouettea sibayi

Silurus aristotelis

Silurus mento

Silvinichthys bortayro

Sinocyclocheilus anophthalmus

Sinocyclocheilus grahami

Siphateles bicolor

Speoplatyrhinus poulsoni

Squalidus banarescui

Squalidus iijimae

Squalius aradensis

Squalius torgalensis

Steindachneridion parahybae

Stygichthys typhlops

Syngnathus watermeyeri

Taenioides jackson

Tanichthys albonubes

Tometes lebaili

\section{Asia: Russia}

Africa: Kowie, Great Fish, Buffalo, Keiskamma and Nahoon River systems, southeast Cape, South Africa

Europe: Tyrrhenian basin from Magra to Garigliano drainages in Italy. Introduced in Lake Scanno (Pescara drainage, Italy), which is the only locality where it is known to survive. Also survived some time in Lake Massaciuccoli (Serchio drainage [north of Pisa], Italy) but the present status of this population is still unknown

Oceania: Australia

\section{Asia: China}

Asia: Erhai Lake in Yunnan, China

Asia: Kul river basin, Iran

Oceania: New Caledonia

Africa: Lake St. Lucia, Lake Sibayi and Kosi Bay, South Africa

Europe: Acheloos drainage in Greece. Introduced in Lakes Pamvotis and Volvi

Asia: endemic to Dian Chi Lake, Yunnan, China

South America: artificial wells in western Argentina

Asia: Yunnan, China

Asia: China

North America: known only from Key Cave in Alabama, USA

Asia: Wu (Ta-du) River basin in central Taiwan

Asia: endemic to Taiwan

Europe: Arade, Algibre and Bordeira basins in the extreme south of Portugal

Europe: Torgal drainage in southern Portugal

South America: Paraíba do Sul and Jequitinhonha River basins in Brazil

South America: upper São Francisco River basin in Minas Gerais, Brazil

Africa: Known only from areas of tidal influence within the Kariega, Kasouga and Bushmans Rivers, South Africa Africa: known only from South Africa

Asia: China and Viet Nam

South America: Mana River and Maroni basins in French Guiana, and Commewine River in Suriname
Freshwater

Freshwater

Freshwater

Freshwater

Freshwater

Freshwater

Freshwater

Freshwater

Freshwater

Freshwater

Freshwater

Freshwater

Freshwater

Freshwater, brackish

Freshwater

Freshwater

Freshwater

Freshwater

Freshwater

Freshwater

Freshwater

Freshwater

Brackish

Freshwater, brackish

Freshwater

Freshwater 
Table 1 (continued)

\begin{tabular}{|c|c|c|}
\hline Species & Distribution & Environment \\
\hline Tor putitora & $\begin{array}{l}\text { Asia: Afghanistan, Pakistan, India, Nepal, Bangladesh, } \\
\text { Bhutan and Mynmar }\end{array}$ & Freshwater \\
\hline Tor tor & Asia: Pakistan, India, Bangladesh, Myanmar, Nepal and Bhutan & Freshwater \\
\hline Trachidermus fasciatus & Asia: Japan, China and Korea & $\begin{array}{l}\text { Marine; freshwater; } \\
\text { brackish }\end{array}$ \\
\hline Trichomycterus chungaraensis & South America: streams of Chungará Lake in Chile & Freshwater \\
\hline Triplophysa siluroides & Asia: Qinghai Province, China & Freshwater \\
\hline Typhlichthys subterraneus & $\begin{array}{l}\text { North America: portions of Alabama, Georgia, Tennessee, } \\
\text { Kentucky, Indiana, Missouri and Arkansas, USA }\end{array}$ & Freshwater \\
\hline Umbra krameri & $\begin{array}{l}\text { Europe: Danube drainage from Vienna to delta; lower reaches } \\
\text { of Dniestr drainage }\end{array}$ & Freshwater \\
\hline Valencia hispanica & $\begin{array}{l}\text { Europe: Spain along the Mediterranean coast between Tortosa } \\
\text { and Cape San Antonio }\end{array}$ & Freshwater \\
\hline Valencia letourneuxi & $\begin{array}{l}\text { Europe: Albania and western Greece, from Lake Butrint to } \\
\text { Alfios drainages, and Corfu and Lefkas islands where it } \\
\text { has been extirpated }\end{array}$ & Freshwater \\
\hline Wallago attu & $\begin{array}{l}\text { Asia: Pakistan to Viet Nam and Indonesia. Reported from } \\
\text { Afghanistan. Lower risk - near threatened status in Western } \\
\text { Ghats, India }\end{array}$ & Freshwater, brackish \\
\hline Xenocypris yunnanensis & Asia: Dianci lake, Yunnan, China & Freshwater \\
\hline Xyrauchen texanus & $\begin{array}{l}\text { North America: Formerly throughout medium to large rivers of } \\
\text { Colorado River basin from Wyoming and Colorado in USA } \\
\text { to Baja California in Mexico. }\end{array}$ & Freshwater \\
\hline Yunnanilus discoloris & Asia: China & Freshwater \\
\hline Zacco chengtui & Asia: Peng-hsien, near Chengtu, Szechwan Province, China & Freshwater \\
\hline Zoogoneticus tequila & North America: Mexico & Freshwater \\
\hline
\end{tabular}

central to this special issue (Helfman 2013; Katz et al. 2013; Nielsen et al. 2013). There is no shortage of regional, national and international attention and publications on the subject of threatened fishes. What is lacking is a clear focus to recognize the basic causes of threats to fishes, or to deal with those concerns. One thing that is very clear, and very important to note from the short articles in the series on Threatened Fishes, is the description of the threats to the species. Perhaps these detailed accounts can serve as the catalysts to support local efforts directed towards species that would otherwise go unnoticed. Clearly everyone concerned about the present status and potential fate of threatened fishes will share our mixed feelings of satisfaction from bringing even this limited number of species accounts to the attention of a broader audience together with the feeling of increasing concern about such obvious predictions for the future of so many fish species.

\section{References}

Albins M, Evans A, Ismail G, Neilsen B, Pusack T, Schemmel E, Smith W, Stoike S, Li HW, Noakes DLG (2013) Can humans coexist with fishes? Environ Biol Fishes 96(10-11):13011313

Froese R, Pauly D (Eds) (2013) FishBase. World Wide Web electronic publication. www. fishbase.org, version (Accessed: 7 August 2013)

Helfman GS (2007) Fish conservation: a guide to understanding and restoring global aquatic biodiversity and fishery resources, Island Press. $608 \mathrm{p}$

Helfman GS (2013) National "versus" global red lists of imperilied fishes: why the discord? Environ Biol Fishes 96(10-11):1159-1168

Katz J, Moyle PB, Quinones RM, Israel J, Purdy S (2013) Impending extinction of salmon, steelhead, and trout (Salmonidae) in California. Environ Biol Fishes 96(10-11):1169-1186

Nielsen J, Ruggerone GT, Zimmerman CE (2013) Adaptive strategies and life history characteristics in a warming climate: Salmon in the Arctic? Environ Biol Fishes 96(10-11):1187-1226

Scott WB, Crossman EJ (1973) Freshwater fishes of Canada. Ottawa, Ontario, $966 \mathrm{p}$ 